American Journal of Applied Sciences 7 (9): 1200-1209, 2010

ISSN 1546-9239

(C) 2010 Science Publications

\title{
Differences in Soil Physical and Chemical Properties of Rehabilitated and Secondary Forests
}

\author{
${ }^{1}$ M.H. Akbar, ${ }^{1}$ O.H. Ahmed, ${ }^{2}$ A.S. Jamaluddin, ${ }^{2}$ N.M. Nik Ab. Majid, \\ ${ }^{2,3}$ H. Abdul-Hamid, ${ }^{4}$ S. Jusop, ${ }^{5}$ A. Hassan, ${ }^{2}$ K.H. Yusof and ${ }^{2,3}$ Arifin Abdu \\ ${ }^{1}$ Department of Crop Science, Faculty of Agriculture and Food Sciences, \\ University Putra Malaysia Bintulu Sarawak Campus, 97008 Bintulu, Sarawak \\ ${ }^{2}$ Department of Forest Management, Faculty of Forestry, \\ ${ }^{3}$ Laboratory of Sustainable Bioresource Management, \\ Institute of Tropical Forestry and Forest Products, \\ ${ }^{4}$ Department of Land Management, Faculty of Agriculture, \\ University Putra Malaysia, 43400 Serdang, Selangor, Malaysia \\ ${ }^{5}$ School of International Tropical Forestry, University Malaysia Sabah, \\ 88999 Sabah, Malaysia
}

\begin{abstract}
Problem statement: The soil properties of tropical rain forest in Southeast Asia have been characterized by several researchers; however empirical data on soil characteristics under rehabilitation program are still limited or even lacking. This research is important to determine the soil physical and chemical properties of a rehabilitated degraded forest land 19 years after planting with various indigenous species in comparison with adjacent secondary forests and to elucidate the soil fertility status in rehabilitated and secondary forests by using Soil Fertility Index (SFI) and Soil Evaluation Factor (SEF). Approach: Soil samples were collected from both locations which were rehabilitated forest and secondary forest (Nirwana forest) at University Putra Malaysia, Bintulu Sarawak Campus. The plot size of each experimental site was $20 \times 20 \mathrm{~m}$. An auger was used to take soil samples from two depths, namely $0-10$ and $10-20 \mathrm{~cm}$. For soil profile, the soil samples were collected from different depths up to $100 \mathrm{~cm}$ according to the soil horizons. The samples were airdried, homogenized and sieved to pass a $2 \mathrm{~mm}$ mesh sieve for further analysis. The physical analysis consisted of bulk density and soil moisture content. For chemical analysis, soil acidity, soil organic matter, total organic carbon, available $\mathrm{P}$, exchangeable $\mathrm{Al}$, exchangeable ammonium and nitrate, exchangeable cations $(\mathrm{Ca}, \mathrm{Mg}, \mathrm{K})$ and Cation Exchange Capacity (CEC) were determined. The soil fertility status was determined based on SFI and SEF values for both rehabilitated and secondary forests. Results: The bulk density of the rehabilitated forest ranged between 0.70 and $1.29 \mathrm{~g} \mathrm{~cm}^{-3}$ and that of the secondary forest was $0.64-0.76 \mathrm{~g} \mathrm{~cm}^{-3}$. The soil moisture content of the rehabilitated forest was $23.31-51.03 \%$ while that of secondary forest was $41.06-41.49 \%$. The range $\mathrm{pH}$ (water) of the rehabilitated forest was 4.5-5.0 and that of the secondary forest range was 4.2-4.3. Furthermore, the content of SOM in the rehabilitated forest was 2.5-5.8\%. On other hand, the range for the secondary was $4.1-4.6 \%$. The exchangeable $\mathrm{Al}$ of the rehabilitated forest was $0.8-2.5 \mathrm{cmol}_{\mathrm{c}} \mathrm{kg}^{-1}$ and that of the secondary forest was 1.6-1.7 $\mathrm{cmol}_{\mathrm{c}} \mathrm{kg}^{-1}$. The CEC of the rehabilitated forest was 1.4-11.8 $\mathrm{cmol}_{\mathrm{c}} \mathrm{kg}^{-1}$, while that of the secondary forest was 4.3-4.5 $\mathrm{cmol}_{\mathrm{c}} \mathrm{kg}^{-1}$. Based on SFI and SEF values, the secondary forest had a lower fertility status compared to the rehabilitated forest. Moreover, the SEF value of the secondary forest was below 5 , while some of the plots of rehabilitated forest had the SEF values greater than 5. Conclusion: It can be concluded that both rehabilitated and secondary forests have significant differences based on selected physical and chemical properties. Moreover, the soil fertility status at rehabilitated plots was comparatively higher than secondary
\end{abstract}

Corresponding Author: Arifin Abdu, Department of Forest Management, Faculty of Forestry, University Putra Malaysia 43400 UPM Sersang, Selangor, Malaysia Tel: +60389467177 Fax: +60389432514 
forest indicating a good potential of 'Miyawaki' forest rehabilitation technique in rehabilitating and replenishing soil fertility status of degraded forest land.

Key words: Soil fertility index, Soil evaluation factor, rehabilitated forest, secondary forest, cation exchange capacity, dipterocarp

\section{INTRODUCTION}

Tropical rainforests cover $6 \%$ of the earth's land surface, yet provide a habitat for more than $50 \%$ of the world's living of plant and animal species (Archard et al., 2002; Mayaux et al., 2005). They are the richest ecosystems in the world in terms of structure and species diversity (Whitmore, 1998). Tropical rainforest of Malaysia is located in South East Asia and comprises Sabah and Sarawak on the island of Kalimantan (Borneo) and Peninsular Malaysia. The total land area of Malaysia is approximately 32.8 million ha, with 13.1 million ha in Peninsular Malaysia, 7.4 and 12.3 million ha in Sabah and Sarawak, respectively (Jomo et al., 2004). In the case of total forest cover in Malaysia, it has been estimated to be 20 million ha or $60 \%$ of its total land area, with the proportion of forested land being higher in Sabah and Sarawak than in Peninsular Malaysia. Of the total forest area, 5.97 million ha are in the Peninsular Malaysia, 4.25 million in Sabah and 9.84 million in Sarawak (Jomo et al., 2004). Malaysia's tropical rainforest is well known as one of the most complex ecosystems in the world where it is home to more than 8,000 species of flowering plants, 2,500 of which are tree species.

Despite increasing recognition of the importance of tropical rain forest, huge areas are becoming degraded forest land as a consequence of deforestation, forest harvesting, shifting cultivation and forest encroachment (Jomo et al., 2004). It was estimated that about 13 million hectares of the world's forests are lost annually due to deforestation (FAO, 2005). According to Butler (2006), approximately 140,200 ha or $0.65 \%$ of Malaysia's forested area are lost annually since 2000. In Sarawak alone, besides forest harvesting and forest encroachment, shifting cultivation is the major cause of land degradation. It was reported that 2.25 million ha were under shifting cultivation in the 1960s and by 1985 , increased to 3.33 million ha (Jomo et al., 2004).

Deforestation is the logging or burning of trees in forested areas. The removal of trees without sufficient reforestation has resulted in damage to habitat and biodiversity loss accompany with increasing soil compaction, erosion and decrease in soil fertility (Geist and Lambin, 2002; Williamson and Neilsen, 2000). Moreover, physical degradation of soil results in reductions in plant growth and increases in the frequency of wild fires are common consequences of forest operations in humid tropical forests.

In order to reverse such degraded forest land into more productive areas, plantation forest or rehabilitation activities are important countermeasures from a global perspective in terms of wood resources, environment and species conservation worldwide. Rehabilitation attempts to return the forest to a stable and productive condition, but not necessarily the original diversity, structure and function. Rehabilitation commonly involves plantation of native and exotic species on degraded forest land. University Putra Malaysia Bintulu Sarawak Campus, Yokohama National University and Japanese Center for International Studies in Ecology initiated a forest rehabilitation program in shifting cultivation area in Bintulu using "Miyawaki" forest rehabilitation technique. "Miyawaki" forest rehabilitation technique starts with field survey by comparing the site's characteristics with an adjacent native forest. The selections of potential natural species are identified from the releve (vegetation sampling) of the adjacent natural forests (Leng et al., 2009).

Furthermore, in order to curtail and manage the degraded forest land properly, accumulation of knowledge on the soils is required. Although several studies have been conducted to characterize the soil properties in Malaysia (Ishizuka et al., 2000; Hattori et al., 2005; Abdu et al., 2007; Zaidey et al., 2010), a crucial information in relation to physical and chemical properties under rehabilitation of degraded forest land with various dipterocarp species is rather limited.

The objective of our study was to determine soil physical and chemical properties of planted forest in comparison with secondary forest and to elucidate the soil fertility status by using Soil Fertility Index (SFI) and Soil Evaluation Factor (SEF).

\section{MATERIALS AND METHODS}

This study was conducted at two different sites, rehabilitate forest and secondary forest (Nirwana forest) at University Putra Malaysia, Bintulu Campus area (latitude $03^{\circ} 12 \mathrm{~N}$ and longitude $113^{\circ} 02 \mathrm{E}$ ). The rehabilitated forest or Malaysia Tropical Forest Regeneration Experimental Project, initially a Joint Research Project between Yokohama National 
University and University Putra Malaysia, formerly known as University Pertanian Malaysia, was sponsored by Mitsubishi Corporation in 1990. This project has been extended as a joint effort between University Putra Malaysia, University Malaysia Sarawak (UNIMAS) and Japanese Center for International Studies in Ecology (JISE) since October 1993. Prior to the project, the site was an abandoned shifting cultivation area. The attempt to recreate a native forest with indigenous trees is a success where the site now is taking on the appearance of a luxuriant forest. The once deserted 50 ha area is now becoming home for 350,000 forest tree seedlings from 126 tree species from the family of dipterocarpaceae and non-dipterocarpaceae. Therefore, tree planting in this area has become an annual event to the community of the parties. In contrast, the adjacent secondary forest of Nirwana forest was a logged over forest for a period of time and left idle without any forest management system.

The mean annual rainfall is about $2993 \mathrm{~mm}$ and the mean daily temperature recorded is $27^{\circ} \mathrm{C}$. The mean monthly relative humidity of the area is usually above $80 \%$ and slightly lower during rainy season. The soils of University Putra Malaysia Bintulu Campus belong to Bekenu and Nyalau (Ultisols) series which are well drained. Bekenu and Nyalau series are characterized by mixed fine loam, 4-15 cm deep light yellowish brown top soil and brownish yellow subsoil. Both series are fine loamy, siliceous, isohyperthermic, red-yellow to yellow Tipik Tualemkuts based on the USDA-Soil Taxonomy Classification System (Soil Survey Staff, 1999).

Soil samples were collected from a rehabilitated forest and secondary forest (Nirwana forest) at University Putra Malaysia, Bintulu Campus. The plot size for each site was $20 \times 20 \mathrm{~m}$. An auger was used to take soil samples from two depths namely 0-10 and 10$20 \mathrm{~cm}$. In order to compare the soil physical and chemical properties as well as soil fertility status at rehabilitated forests, the soils at adjacent secondary forest were collected. Proper labeling was conducted to avoid identification errors during transfer. Each plot was divided into two different sites. Then, the samples were taken from each corner and in the middle and homogenized to make composite sample. For soil profile, the soil samples were collected from different depths up to $100 \mathrm{~cm}$ according to the soil horizons. The samples were air-dried, homogenized and sieved to pass a $2 \mathrm{~mm}$ mesh sieve for further analysis. The physical analysis consisted of bulk density and soil moisture content. For chemical analysis soil acidity, Soil Organic Matter (SOM), Total Organic Carbon (TOC), available $\mathrm{P}$, exchangeable $\mathrm{Al}$, exchangeable ammonium and nitrate, exchangeable cations $(\mathrm{Ca}, \mathrm{Mg}, \mathrm{K})$ and Cation Exchange Capacity (CEC) were determined.

Bulk density was determined using the coring method. The gravimetric method is the simplest method to determine soil moisture content. Soil sample was weighed before and after the sample was oven dried at $105^{\circ} \mathrm{C}$ until constant weight was attained. The Electrical Conductivity (EC) and $\mathrm{pH}\left(\mathrm{H}_{2} \mathrm{O}\right)$ values were measured by mixing soil with deionized water at a ratio of 1:5 (soil: water) followed by shaking the mixture for $1 \mathrm{~h}$ and using platinum for EC or glass electrode for $\mathrm{pH}$. The $\mathrm{pH} \mathrm{KCl}$ of the soils was measured with a glass electrode using a soil solution 1:5 (soil: $1 \mathrm{M} \mathrm{KCl)} \mathrm{after}$ shaking for $1 \mathrm{~h}$. The exchangeable acidity and exchangeable aluminum were extracted once with $1 \mathrm{M}$ $\mathrm{KCl}$. The exchangeable acidity was determined by the titration method with $0.01 \mathrm{M} \mathrm{NaOH}$ and the content of exchangeable $\mathrm{Al}$ with $0.01 \mathrm{M} \mathrm{HCl}$ (Sumner and Stewart, 1992). Determination of available P was done by Bray 2 method. Soil available P was extracted with a mixture of $\mathrm{HCl}$ and $\mathrm{NH}_{4} \mathrm{~F}$ (Kuo, 1996). Exchangeable cations $(\mathrm{Ca}, \mathrm{Mg}, \mathrm{K})$ were determined by leaching method using $1 \mathrm{M}$ ammonium acetate at $\mathrm{pH}$ 7. The concentrations of $\mathrm{Ca}, \mathrm{Mg}$ and $\mathrm{K}$ were determined by atomic absorption spectophotometry. After removing the excessive ammonium, the soil was extracted with $100 \mathrm{~g} \mathrm{~L}^{-1} \mathrm{NaCl}$ solution and the supernatatnt was used to determine the Cation Exchange Capacity (CEC) using the Kjeldahl distillation and titration method. The exchangeable ammonium and nitrate were determined using $2 \mathrm{M} \mathrm{KCl}$ followed by steam distillation method as described by Mulvaney (1996). The content of organic matter and total organic carbon were determined using loss-on-ignition method (Murugayah et al., 2009).

In order to evaluate soil fertility, Soil Fertility Index (SFI) (Moran et al., 2000) and Soil Evaluation Factor (SEF) (Lu et al., 2002) were used. The SFI and SEF indices were calculated to quantify the intensity of land degradation in the study site based on the following equations:

Soil Fertility Index $(\mathrm{SFI})=\mathrm{pH}+$ organic matter $(\%$, dry soil basis) + available $\mathrm{P}\left(\mathrm{mg} \mathrm{kg}^{-1}\right.$ dry soil $)+$ exch $\mathrm{K}$ $\left(\mathrm{cmol}_{\mathrm{c}} \mathrm{kg}^{-1}\right)+$ exch $\mathrm{Ca}\left(\mathrm{cmol}_{\mathrm{c}} \mathrm{kg}^{-1}\right)+$ exch $\mathrm{Mg}$ $\left(\mathrm{cmol}_{\mathrm{c}} \mathrm{kg}^{-1}\right)$-exch $\mathrm{Al}\left(\mathrm{cmol}_{\mathrm{c}} \mathrm{kg}^{-1}\right)$

Soil Evaluation Factor $(\mathrm{SEF})=\left[\mathrm{Exch} \mathrm{K}\left(\mathrm{cmol}_{\mathrm{c}} \mathrm{kg}^{-1}\right)+\right.$ Exch $\mathrm{Ca}\left(\mathrm{cmol}_{\mathrm{c}} \mathrm{kg}^{-1}\right)+$ Exch $\mathrm{Mg}\left(\mathrm{cmol}_{\mathrm{c}} \mathrm{kg}^{-1}\right)-\log (1+$ $\left.\operatorname{exch~} \mathrm{Al}\left(\mathrm{cmol}_{\mathrm{c}} \mathrm{kg}^{-1}\right)\right] \times$ organic matter $(\%$, dry soil $)+5$

Both indices (SFI and SEF) were developed and used to assess the soil biomass and fertility status under 
succession of secondary forest in the Amazon humid tropical forest of Brazil. The suitability of SFI and SEF indices were used in the present study to determine the soil fertility between rehabilitated and secondary forests. Analysis of variance and Tukey's (HSD) were used for the statistical test. Statistical Analysis System (SAS Ver. 9.2) was used for the statistical analysis.

\section{RESULTS}

The highest mean value of bulk density was $1.29 \mathrm{~g}$ $\mathrm{cm}^{-3}$ for Plot 2008, while the lowest mean $0.64 \mathrm{~g} \mathrm{~cm}^{-3}$ for Nirwana 2 as shown in Table 1 .

Table 1:Bulk density of rehabilitated forest (different ages) and secondary forests (Nirwana 1 and 2)

\begin{tabular}{ll}
\hline & Means \\
Plots/years of planting & Bulk density $\left(\mathrm{g} \mathrm{cm}^{-3}\right)$ \\
\hline 1991 & $0.97^{\mathrm{bc}}$ \\
1993 & $0.97^{\mathrm{bc}}$ \\
1995 & $0.98^{\mathrm{bc}}$ \\
1996 & $0.92^{\mathrm{bcd}}$ \\
1997 & $0.70^{\mathrm{de}}$ \\
1998 & $0.85^{\mathrm{bcde}}$ \\
1999 & $0.84^{\mathrm{bcde}}$ \\
2000 & $0.91^{\mathrm{bcd}}$ \\
2001 & $0.9^{\mathrm{bcd}}$ \\
2002 & $0.95^{\mathrm{bcd}}$ \\
2003 & $0.85^{\mathrm{bcde}}$ \\
2004 & $1.08^{\mathrm{ab}}$ \\
2005 & $0.89^{\mathrm{bcde}}$ \\
2006 & $0.75^{\mathrm{cde}}$ \\
2007 & $1.04^{\mathrm{ab}}$ \\
2008 & $1.29^{\mathrm{a}}$ \\
Nirwana 1 & $0.76^{\mathrm{cde}}$ \\
Nirwana 2 & $0.64^{\mathrm{e}}$ \\
\hline Note: Means with the different letters & within columns are \\
significantly different at 5\% between plots and secondary forests \\
according to ANOVA and followed by a Tukey's (HSD) test
\end{tabular}

Table 2: Moisture content of rehabilitated forest (different ages) and secondary forests (Nirwana 1 and 2)

\begin{tabular}{ll}
\hline & Means \\
Plots/years of planting & Bulk density $\left(\mathrm{g} \mathrm{cm}^{-3}\right)$ \\
\hline 1991 & $39.17^{\mathrm{abc}}$ \\
1993 & $34.07^{\mathrm{bcd}}$ \\
1995 & $34.76^{\mathrm{bcd}}$ \\
1996 & $30.98^{\mathrm{bcd}}$ \\
1997 & $26.49^{\mathrm{cd}}$ \\
1998 & $28.08^{\mathrm{bcd}}$ \\
1999 & $31.38^{\mathrm{bcd}}$ \\
2000 & $37.47^{\mathrm{abcd}}$ \\
2001 & $32.69^{\mathrm{bcd}}$ \\
2002 & $38.72^{\mathrm{abc}}$ \\
2003 & $51.03^{\mathrm{a}}$ \\
2004 & $32.91^{\mathrm{bcd}}$ \\
2005 & $37.90^{\mathrm{abcd}}$ \\
2006 & $50.96^{\mathrm{a}}$ \\
2007 & $40.47^{\mathrm{abc}}$ \\
2008 & $23.31^{\mathrm{d}}$ \\
Nirwana 1 & $41.49^{\mathrm{ab}}$ \\
Nirwana 2 & $41.06^{\mathrm{abc}}$
\end{tabular}

Note: Means with the different letters within columns are significantly different at 5\% between plots and secondary forests according to ANOVA and followed by a Tukey's (HSD) test
Table 2 shows the highest mean value of moisture content was $51.03 \%$ for Plot 2003 and the lowest mean was $23.31 \%$ for Plot 2008 .

Table 3 shows the mean values of soil acidity $\left(\mathrm{pH}(\mathrm{KCl})\right.$ and $\left.\mathrm{pH}\left(\mathrm{H}_{2} \mathrm{O}\right)\right)$ at rehabilitated and secondary forests. For $\mathrm{pH}$ in $\mathrm{KCl}$, the highest mean was 4.05 for Plot1996, followed by Plot 2008. The lowest mean value was 3.59 for Nirwana 2. In addition, Table 3 also shows that the highest mean of $\mathrm{pH}\left(\mathrm{H}_{2} \mathrm{O}\right)$ was 5.03 for Plot 2005. However, the lowest mean was 4.22 for Nirwana 2.

Table 3: Soil acidity (pH $\mathrm{KCl}$ and $\mathrm{pH}$ Water) of rehabilitated forest (different ages) and secondary forests (Nirwana 1 and 2)

\begin{tabular}{lll}
\hline & Means & \\
Plots/years of planting & KCl & $\mathrm{H}_{2} \mathrm{O}$ \\
\hline 1991 & $3.73^{\text {def }}$ & $4.51^{\text {bed }}$ \\
1993 & $3.74^{\text {def }}$ & $4.51^{\text {bcd }}$ \\
1995 & $3.97^{\text {bb }}$ & $4.89^{\mathrm{a}}$ \\
1996 & $4.05^{\mathrm{a}}$ & $5.01^{\mathrm{a}}$ \\
1997 & $3.93^{\text {abc }}$ & $4.84^{\mathrm{ab}}$ \\
1998 & $3.95^{\mathrm{abc}}$ & $4.72^{\mathrm{abc}}$ \\
1999 & $3.88^{\mathrm{bcd}}$ & $4.66^{\mathrm{abc}}$ \\
2000 & $3.93^{\text {abc }}$ & $4.74^{\mathrm{abc}}$ \\
2001 & $3.94^{\mathrm{abc}}$ & $4.94^{\mathrm{a}}$ \\
2002 & $3.72^{\mathrm{ef}}$ & $4.84^{\mathrm{ab}}$ \\
2003 & $3.74^{\text {def }}$ & $4.72^{\mathrm{abc}}$ \\
2004 & $3.91^{\text {abc }}$ & $4.97^{\mathrm{a}}$ \\
2005 & $3.93^{\text {abc }}$ & $5.03^{\mathrm{a}}$ \\
2006 & $3.83^{\mathrm{bcde}}$ & $4.93^{\mathrm{a}}$ \\
2007 & $3.87^{\mathrm{bcde}}$ & $4.85^{\mathrm{ab}}$ \\
2008 & $4.04^{\mathrm{a}}$ & $5.00^{\mathrm{a}}$ \\
Nirwana 1 & $3.80^{\mathrm{cde}}$ & $4.37^{\mathrm{cd}}$ \\
Nirwana 2 & $3.59^{\mathrm{f}}$ & $4.22^{\mathrm{d}}$ \\
\hline Note: Means with the different letters within columns are \\
significantly different at 5\% between plots and secondary forests \\
according to ANOVA and followed by a Tukey's (HSD) test
\end{tabular}
according to ANOVA and followed by a Tukey's (HSD) test

Table 4: Percentage of Soil Organic Matter (SOM) and total Organic Carbon (TOC) of rehabilitated forest (different ages) and secondary forests (Nirwana 1 and 2)

\begin{tabular}{|c|c|c|}
\hline \multirow[b]{2}{*}{ Plots/years of planting } & \multicolumn{2}{|l|}{ Means } \\
\hline & $\operatorname{SOM}(\%)$ & TOC $(\%)$ \\
\hline 1991 & $4.8^{\mathrm{abc}}$ & $2.78^{\mathrm{abc}}$ \\
\hline 1993 & $3.95^{\text {bcde }}$ & $2.29^{\text {bcde }}$ \\
\hline 1995 & $3.87^{\text {bcde }}$ & $2.24^{\text {bcde }}$ \\
\hline 1996 & $2.77^{\mathrm{de}}$ & $1.61^{\mathrm{de}}$ \\
\hline 1997 & $3.65^{\text {bcde }}$ & $2.12^{\text {bcde }}$ \\
\hline 1998 & $4.17^{\text {abcde }}$ & $2.42^{\text {abcde }}$ \\
\hline 1999 & $4.31^{\mathrm{abcd}}$ & $2.49^{\text {abcd }}$ \\
\hline 2000 & $4.09^{\text {abcde }}$ & $2.38^{\text {abcde }}$ \\
\hline 2001 & $3.91^{\text {bcde }}$ & $2.27^{\text {bcde }}$ \\
\hline 2002 & $5.87^{\mathrm{a}}$ & $3.40^{\mathrm{a}}$ \\
\hline 2003 & $5.29^{\mathrm{ab}}$ & $3.07^{\mathrm{ab}}$ \\
\hline 2004 & $3.15^{\mathrm{cde}}$ & $1.83^{\text {cde }}$ \\
\hline 2005 & $4.03^{\text {bcde }}$ & $2.34^{\text {bcde }}$ \\
\hline 2006 & $4.69^{\mathrm{abc}}$ & $2.72^{\mathrm{abc}}$ \\
\hline 2007 & $3.29^{\text {cde }}$ & $1.91^{\text {cde }}$ \\
\hline 2008 & $2.53^{\mathrm{e}}$ & $1.47^{\mathrm{e}}$ \\
\hline Nirwana 1 & $4.09^{\text {bcde }}$ & $2.37^{\text {bcde }}$ \\
\hline Nirwana 2 & $4.62^{\mathrm{abc}}$ & $2.68^{\mathrm{abc}}$ \\
\hline
\end{tabular}


Percentage of soil organic matter for the rehabilitated forest and secondary forest are shown in Table 4. Plot 2002 had the highest mean $(5.87 \%)$ and the lowest was $2.53 \%$ for Plot 2008. Percentage of total organic carbon of the rehabilitated forest and secondary forest are shown in Table 4. Plot 2002 had the highest mean $(3.40 \%)$ and the lowest was for Plot 2008 (1.47\%).

The highest content for exchangeable $\mathrm{Al}$ was in plot 2003, while the lowest was in Plot 2008 as shown in Table 5. Table 6 shows the mean value of cation exchange capacity at rehabilitated and secondary forests. The highest mean was in Plot 2002 and the lowest mean was in Plot 2008.

Table 5: Exchangeable Aluminum (Al) of rehabilitated forest (different ages) and secondary forests (Nirwana 1 and 2)

\begin{tabular}{|c|c|}
\hline & Means \\
\hline Plots/years of planting & Exchangeable $\mathrm{Al}\left(\mathrm{cmol}_{\mathrm{C}} \mathrm{kg}^{-1}\right)$ \\
\hline 1991 & $2.11^{\mathrm{abc}}$ \\
\hline 1993 & $1.50^{\text {cdef }}$ \\
\hline 1995 & $1.40^{\mathrm{def}}$ \\
\hline 1996 & $1.01^{\mathrm{ef}}$ \\
\hline 1997 & $1.25^{\mathrm{def}}$ \\
\hline 1998 & $1.39^{\text {def }}$ \\
\hline 1999 & $1.42^{\text {def }}$ \\
\hline 2000 & $1.56^{\text {cde }}$ \\
\hline 2001 & $0.97^{\mathrm{ef}}$ \\
\hline 2002 & $2.35^{\mathrm{ab}}$ \\
\hline 2003 & $2.54^{\mathrm{a}}$ \\
\hline 2004 & $1.18^{\text {def }}$ \\
\hline 2005 & $0.88^{\mathrm{f}}$ \\
\hline 2006 & $1.56^{\text {cde }}$ \\
\hline 2007 & $1.04^{\mathrm{ef}}$ \\
\hline 2008 & $0.84^{\mathrm{f}}$ \\
\hline Nirwana 1 & $1.64^{\text {cde }}$ \\
\hline Nirwana 2 & $1.78^{\mathrm{bcd}}$ \\
\hline
\end{tabular}

Table 6: Cation Exchange Capacity (CEC) of rehabilitated (different ages) forest and secondary forests (Nirwana 1 and 2)

\begin{tabular}{|c|c|}
\hline & Means \\
\hline Plots/years of planting & $\mathrm{CEC}\left(\mathrm{cmol}_{\mathrm{C}} \mathrm{kg}^{-1}\right)$ \\
\hline 1991 & $8.20^{\mathrm{abc}}$ \\
\hline 1993 & $2.70^{\text {cd }}$ \\
\hline 1995 & $6.88^{\text {abcd }}$ \\
\hline 1996 & $2.63^{\mathrm{cd}}$ \\
\hline 1997 & $5.90^{\text {abcd }}$ \\
\hline 1998 & $6.20^{\text {abcd }}$ \\
\hline 1999 & $6.48^{\text {abcd }}$ \\
\hline 2000 & $5.58^{\mathrm{abcd}}$ \\
\hline 2001 & $1.90^{\mathrm{cd}}$ \\
\hline 2002 & $11.85^{\mathrm{a}}$ \\
\hline 2003 & $10.10^{\mathrm{ab}}$ \\
\hline 2004 & $4.38^{\mathrm{bcd}}$ \\
\hline 2005 & $4.83^{\text {bcd }}$ \\
\hline 2006 & $5.4^{\text {abcd }}$ \\
\hline 2007 & $2.05^{\mathrm{cd}}$ \\
\hline 2008 & $1.43^{\mathrm{d}}$ \\
\hline Nirwana 1 & $4.93^{\mathrm{bcd}}$ \\
\hline Nirwana 2 & $4.38^{\text {bcd }}$ \\
\hline
\end{tabular}

Exchangeable ammonium $\left(\mathrm{NH}_{4}{ }^{+}-\mathrm{N}\right)$ and exchangeable nitrate $\left(\mathrm{NO}_{3}{ }^{-} \mathrm{N}\right)$ of the rehabilitated forest and secondary forest are shown in Table 7. For exchangeable $\left(\mathrm{NH}_{4}{ }^{+}-\mathrm{N}\right)$, the highest mean was 43.78 ppm for Plot 1991 and Nirwana 1, while the lowest mean was $17.51 \mathrm{ppm}$ for Plots 1999 and 2000. However, for exchangeable nitrate $\left(\mathrm{NO}_{3}{ }^{-} \mathrm{N}\right)$ the highest mean was 22.77 ppm for Plot 1997 and Nirwana 1, while the lowest mean was 5.25 ppm for plot 2007 and Nirwana 2.

Table 7: Exchangeable ammonium $\left(\mathrm{NH}_{4}{ }^{+}-\mathrm{N}\right)$ and exchangeable nitrate $\left(\mathrm{NO}_{3}{ }^{-} \mathrm{N}\right)$ of rehabilitated forest (different ages) and secondary forests (Nirwana 1 and 2)

\begin{tabular}{|c|c|c|}
\hline \multirow[b]{2}{*}{ Plots/years of planting } & \multicolumn{2}{|l|}{ Means } \\
\hline & $\mathrm{NH}_{4}^{+}-\mathrm{N}(\mathrm{ppm})$ & $\mathrm{NO}_{3}{ }^{-} \mathrm{N}(\mathrm{ppm})$ \\
\hline 1991 & $43.78^{\mathrm{a}}$ & $14.01^{\mathrm{a}}$ \\
\hline 1993 & $31.52^{\text {abcd }}$ & $8.77^{\mathrm{b}}$ \\
\hline 1995 & $31.52^{\text {abcd }}$ & $17.51^{\mathrm{a}}$ \\
\hline 1996 & $38.53^{\mathrm{ab}}$ & $7.01^{\mathrm{b}}$ \\
\hline 1997 & $28.02^{\text {abcd }}$ & $22.77^{\mathrm{a}}$ \\
\hline 1998 & $26.23^{\mathrm{abcd}}$ & $19.26^{\mathrm{a}}$ \\
\hline 1999 & $17.51^{\mathrm{d}}$ & $12.26^{\mathrm{a}}$ \\
\hline 2000 & $17.51^{\mathrm{d}}$ & $19.26^{\mathrm{a}}$ \\
\hline 2001 & $24.52^{\mathrm{bcd}}$ & $14.01^{\mathrm{a}}$ \\
\hline 2002 & $21.02^{\text {bcd }}$ & $7.01^{\mathrm{b}}$ \\
\hline 2003 & $35.03^{\mathrm{abcd}}$ & $10.51^{\mathrm{a}}$ \\
\hline 2004 & $36.78^{\mathrm{abc}}$ & $7.01^{\mathrm{a}}$ \\
\hline 2005 & $22.77^{\mathrm{bcd}}$ & $14.01^{\mathrm{a}}$ \\
\hline 2006 & $28.02^{\text {abcd }}$ & $21.02^{\mathrm{a}}$ \\
\hline 2007 & $19.26^{\text {cd }}$ & $5.25^{\mathrm{b}}$ \\
\hline 2008 & $31.52^{\mathrm{abcd}}$ & $21.02^{\mathrm{a}}$ \\
\hline Nirwana 1 & $43.78^{\mathrm{a}}$ & $22.77^{\mathrm{a}}$ \\
\hline Nirwana 2 & $31.52^{\text {abcd }}$ & $5.25^{\mathrm{b}}$ \\
\hline
\end{tabular}

Note: Means with the different letters within columns are significantly different at 5\% between plots and secondary forests according to ANOVA and followed by a Tukey's (HSD) test

Table 8: Available $\mathrm{P}$ of rehabilitated (different ages) forest and secondary forests (Nirwana 1 and 2)

\begin{tabular}{lc}
\hline Plots/years of planting & $\begin{array}{l}\text { Means } \\
\text { Available } \mathrm{P}\left(\mathrm{mg} \mathrm{kg}^{-1}\right)\end{array}$ \\
\hline 1991 & $10.92^{\mathrm{a}}$ \\
1993 & $1.99^{\mathrm{b}}$ \\
1995 & $1.28^{\mathrm{b}}$ \\
1996 & $1.42^{\mathrm{b}}$ \\
1997 & $1.60^{\mathrm{b}}$ \\
1998 & $1.70^{\mathrm{b}}$ \\
1999 & $2.36^{\mathrm{b}}$ \\
2000 & $2.99^{\mathrm{b}}$ \\
2001 & $2.32^{\mathrm{b}}$ \\
2002 & $2.58^{\mathrm{b}}$ \\
2003 & $1.75^{\mathrm{b}}$ \\
2004 & $2.49^{\mathrm{b}}$ \\
2005 & $2.87^{\mathrm{b}}$ \\
2006 & $2.34^{\mathrm{b}}$ \\
2007 & $2.70^{\mathrm{b}}$ \\
2008 & $1.68^{\mathrm{b}}$ \\
Nirwana 1 & $1.79^{\mathrm{b}}$ \\
Nirwana 2 & $2.47^{\mathrm{b}}$ \\
\hline Note: Means with the different letters within columns are \\
significantly different at 5\% between plots and secondary forests \\
according to ANOVA and followed by a Tukey's (HSD) test
\end{tabular}


The mean values of available $\mathrm{P}$ between plots are shown in Table 8. The available P of Plot 1991 was significantly higher $\left(10.92 \mathrm{mg} \mathrm{kg}^{-1}\right)$ than those of the other plots.

Table 9 shows the mean values for exchangeable cations $(\mathrm{Ca}, \mathrm{Mg}$ and $\mathrm{K}$ ) between rehabilitated and secondary forests. The highest mean for Ca was 0.48 $\mathrm{cmol}_{\mathrm{C}} \mathrm{kg}^{-1}$ in Plot 2006. For $\mathrm{Mg}$, the highest mean was $0.21 \mathrm{cmol}_{\mathrm{c}} \mathrm{kg}^{-1}$ in Plot 1991 followed by Plot 2006, 0.17 $\mathrm{cmol}_{\mathrm{c}} \mathrm{kg}^{-1}$. For $\mathrm{K}$, the highest mean was $0.14 \mathrm{cmol}_{\mathrm{c}} \mathrm{kg}^{-1}$ in Plot 1991. However, the lowest mean for Ca was $0.07 \mathrm{cmol}_{\mathrm{c}} \mathrm{kg}^{-1}$ in Plot Nirwana 1 . For $\mathrm{Mg}$, the lowest mean was $0.03 \mathrm{cmol}_{\mathrm{c}} \mathrm{kg}^{-1}$ in Plot 2001 while for $\mathrm{K}$ the lowest mean value was $0.05 \mathrm{cmol}_{\mathrm{c}} \mathrm{kg}^{-1}$ in Plot 2005 .

Table 9: Exchangeable cations of rehabilitated forest (different ages) and secondary forests (Nirwana 1 and 2)

\begin{tabular}{lccc}
\hline & Means & & \\
Plots/years of planting & $\mathrm{Ca}^{2+}$ & $\mathrm{Mg}^{2+}\left(\mathrm{cmol}_{\mathrm{c}} \mathrm{kg}^{-1}\right)$ & $\mathrm{K}^{+}$ \\
\hline 1991 & $0.23^{\mathrm{ab}}$ & $0.21^{\mathrm{a}}$ & $0.14^{\mathrm{a}}$ \\
1993 & $0.20^{\mathrm{ab}}$ & $0.16^{\mathrm{ab}}$ & $0.11^{\mathrm{ab}}$ \\
1995 & $0.12^{\mathrm{ab}}$ & $0.08^{\mathrm{c}}$ & $0.08^{\mathrm{ab}}$ \\
1996 & $0.08^{\mathrm{ab}}$ & $0.06^{\mathrm{c}}$ & $0.08^{\mathrm{ab}}$ \\
1997 & $0.08^{\mathrm{ab}}$ & $0.07^{\mathrm{c}}$ & $0.09^{\mathrm{ab}}$ \\
1998 & $0.08^{\mathrm{ab}}$ & $0.06^{\mathrm{c}}$ & $0.09^{\mathrm{ab}}$ \\
1999 & $0.15^{\mathrm{ab}}$ & $0.09^{\mathrm{bc}}$ & $0.09^{\mathrm{ab}}$ \\
2000 & $0.14^{\mathrm{ab}}$ & $0.08^{\mathrm{c}}$ & $0.09^{\mathrm{ab}}$ \\
2001 & $0.08^{\mathrm{ab}}$ & $0.03^{\mathrm{c}}$ & $0.05^{\mathrm{b}}$ \\
2002 & $0.10^{\mathrm{ab}}$ & $0.06^{\mathrm{c}}$ & $0.10^{\mathrm{ab}}$ \\
2003 & $0.14^{\mathrm{ab}}$ & $0.09^{\mathrm{bc}}$ & $0.09^{\mathrm{ab}}$ \\
2004 & $0.21^{\mathrm{ab}}$ & $0.07^{\mathrm{c}}$ & $0.09^{\mathrm{ab}}$ \\
2005 & $0.47^{\mathrm{ab}}$ & $0.06^{\mathrm{c}}$ & $0.05^{\mathrm{b}}$ \\
2006 & $0.48^{\mathrm{a}}$ & $0.17^{\mathrm{a}}$ & $0.11^{\mathrm{ab}}$ \\
2007 & $0.28^{\mathrm{ab}}$ & $0.06^{\mathrm{c}}$ & $0.07^{\mathrm{b}}$ \\
2008 & $0.23^{\mathrm{ab}}$ & $0.06^{\mathrm{c}}$ & $0.08^{\mathrm{ab}}$ \\
Nirwana 1 & $0.07^{\mathrm{b}}$ & $0.05^{\mathrm{c}}$ & $0.10^{\mathrm{ab}}$ \\
Nirwana 2 & $0.09^{\mathrm{ab}}$ & $0.05^{\mathrm{c}}$ & $0.10^{\mathrm{ab}}$ \\
\hline Note: Means with the different letters within columns are \\
significantly different at $5 \%$ between plots and secondary forests \\
according to ANOVA and followed by a Tukeys's (HSD) test
\end{tabular}

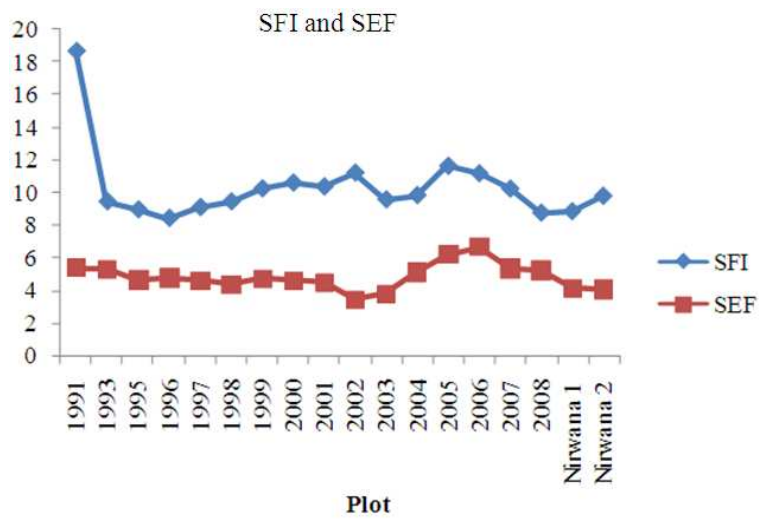

Fig. 1: Soil fertility index and soil evaluation factor between plots and secondary forests
Soil Fertility Index (SFI) and Soil Evaluation Factor (SEF) for rehabilitated forest and secondary forest are shown in Fig. 1. SFI showed higher value than SEF. For SFI, Plot 1991 had the highest value compared to other plots. The lowest was in Plot 1996 However, for SEF the highest value was in Plot 2006 and the lowest was in Plot 2002.

\section{DISCUSSION}

Plot 2008 had higher bulk density compared than other rehabilitated plots since the area had fewer plants with less roots. Root elongation increases soil porosity. The pore in the soils develops due to the penetrations of roots, worms and other forms of soil life (Tan, 2005). The secondary forest had a low bulk density due to higher penetration of roots, accumulation of organic matter and soil life. Bulk density is influenced by the content of organic matter. According to Alexander (1989) the higher the organic matter content consequently decreased the value of the bulk density of the soils. This is consistent with Plot 2008 since it had the lowest content of organic matter (Table 4).

The acidity of the forest soil was due to the presence of exchangeable $\mathrm{Al}^{3+}$ and $\mathrm{H}^{+}$. Moreover, the acidity may be caused by water deficiency due to drought. When this occurs, root mat develops on the surface layer resulting in high carbon content. Besides, soil surface also affect the acidity since Plot 1991 and Plot 1993 had a lot of forest litter compared than other rehabilitated plots.

Most plants grow better in soils with a slightly acid reaction. Nearly all plants are available in optimal amounts for plants growth in this $\mathrm{pH}$ range. According to Tan (2005), some available nutrients are deficient in $\mathrm{pH}$ below 6.0. Hence, many other soil properties and processes are affected by soil $\mathrm{pH}$, such as clay mineral formation and microbial activity. Sakurai et al. (1995; 1998) stated that tree growth and root elongation were restricted by a combination of a heavy texture with strong acidity. In addition, the soil acidity also has a relationship with growing vegetation. A study conducted by Juo and Manu (1996), showed that growing vegetation tended to decrease soil $\mathrm{pH}$, with low nutrient stocks.

Based on the soil profile (Table 10), the soil $\mathrm{pH}$ increased with increasing depth. The Al concentrations and organic matter influenced the soil acidity. According to Zaidey et al. (2010) the increase of $\mathrm{pH}$ with increasing depth may be related to the contents of $\mathrm{Fe}$ and $\mathrm{Al}$ oxides, while the content of organic matter exhibit high and low $\mathrm{pH}$ values. 
Am. J. Applied Sci., 7 (9): 1200-1209, 2010

Table 10: Selected soil chemical properties (soil profiles) at rehabilitated and secondary forests

\begin{tabular}{|c|c|c|c|c|c|c|c|c|c|c|c|c|c|c|c|}
\hline \multirow{3}{*}{$\begin{array}{l}\text { Plot/years } \\
\text { of planting }\end{array}$} & \multirow[b]{3}{*}{ Depth $(\mathrm{cm})$} & \multirow[b]{3}{*}{ Horizon } & \multirow[b]{3}{*}{$\mathrm{pH}(\mathrm{KCl})$} & \multirow[b]{3}{*}{$\mathrm{pH}\left(\mathrm{H}_{2} \mathrm{O}\right)$} & \multicolumn{11}{|c|}{$\left(\mathrm{cmol}_{\mathrm{c}} \mathrm{kg}^{-1}\right)$} \\
\hline & & & & & \multicolumn{5}{|c|}{ Exchangeable cations } & \multirow{2}{*}{$\begin{array}{l}\text { Exch. } \mathrm{NH}_{4}{ }^{+} \\
(\mathrm{ppm})\end{array}$} & \multirow{2}{*}{$\begin{array}{l}\left(\mathrm{mg} \mathrm{kg}^{-1}\right) \\
\text { Exch. } \mathrm{NO}_{3}^{-}\end{array}$} & \multirow{2}{*}{$\begin{array}{l}\left(\mathrm{mg} \mathrm{kg}^{-1}\right) \\
\text { Av. } \mathrm{P}_{2} \mathrm{O}_{5}\end{array}$} & \multirow{2}{*}{$\begin{array}{l}(\%) \\
\text { SOM }\end{array}$} & \multirow[b]{2}{*}{$\begin{array}{l}(\%) \\
\text { TOC }\end{array}$} & \multirow{2}{*}{$\begin{array}{l}\left(\mathrm{cmol}_{\mathrm{c}} \mathrm{kg}^{-1}\right) \\
\text { SFI }\end{array}$} \\
\hline & & & & & $\mathrm{Ca}^{2+}$ & $\mathrm{Mg}^{2+}$ & $\mathrm{K}^{+}$ & $\mathrm{Al}^{3+}$ & CEC & & & & & & \\
\hline Phase 1 & $0-17$ & $\mathrm{~A}$ & 3.65 & 4.40 & 0.24 & 0.27 & 0.07 & 1.96 & 4 & 7 & nd & 4.20 & 7.2 & 4.18 & 14.26 \\
\hline \multirow[t]{3}{*}{1991} & $17-60$ & Bt1 & 3.84 & 4.31 & 0.08 & 0.04 & 0.03 & 1.56 & 7.6 & nd & nd & 0.19 & 4.4 & 2.55 & 7.42 \\
\hline & $60-106$ & $\mathrm{Bt} 2$ & 3.93 & 4.46 & 0.03 & 0.07 & 0.03 & 2.24 & 6.3 & nd & nd & nd & 1.6 & 0.93 & 3.93 \\
\hline & $106-150$ & $\mathrm{Bt} 3$ & 3.97 & 4.61 & 0.03 & 0.04 & 0.03 & 1.34 & 5 & nd & nd & nd & 7.8 & 4.52 & 11.14 \\
\hline Phase 2 & $0-20$ & A & 3.78 & 4.55 & 0.07 & 0.16 & 0.05 & 1.50 & 4.4 & 7 & nd & 2.05 & 5.2 & 3.02 & 10.73 \\
\hline \multirow{3}{*}{1995} & $20-40$ & B & 3.81 & 4.45 & 0.02 & 0.12 & 0.06 & 1.26 & 9.7 & 7 & nd & 0.65 & 5.4 & 3.13 & 9.43 \\
\hline & $40-90$ & $\mathrm{BC} 1$ & 3.86 & 4.71 & 0.02 & 0.09 & 0.05 & 2.28 & 9.4 & nd & nd & 0.12 & 5 & 2.90 & 7.7 \\
\hline & $90-150$ & $\mathrm{BC} 2$ & 3.87 & 4.53 & 0.01 & 0.10 & 0.05 & 1.50 & 8.4 & 7 & nd & 0.18 & 3.6 & 2.09 & 6.97 \\
\hline Phase 3 & $0-15$ & A & 3.77 & 4.52 & 0.02 & 0.05 & 0.07 & 1.66 & 5.5 & 7 & nd & 1.23 & 6.4 & 3.71 & 10.6 \\
\hline \multirow[t]{3}{*}{2002} & $15-42$ & Bt1 & 3.94 & 4.61 & 0.01 & 0.02 & 0.03 & 1.64 & 5.6 & nd & nd & 0.07 & 4.6 & 2.67 & 7.69 \\
\hline & $42-69$ & $\mathrm{Bt} 2$ & 3.98 & 4.81 & 0.03 & 0.02 & 0.04 & 1.80 & 6 & 7 & nd & 0.12 & 5.2 & 3.02 & 8.38 \\
\hline & $69-100$ & $\mathrm{C}$ & 3.98 & 4.92 & 0.01 & 0.02 & 0.03 & 1.78 & 4.3 & 7 & nd & 0.03 & 4.1 & 2.45 & 5.67 \\
\hline Phase 4 & $0-16$ & A & 3.81 & 4.24 & 0.16 & 0.07 & 0.06 & 1.46 & 5 & nd & nd & 1.23 & 6 & 3.48 & 10.14 \\
\hline \multirow{4}{*}{2008} & $16-46$ & Bt1 & 4.05 & 4.94 & 0.07 & 0.02 & 0.04 & 1.96 & 4.6 & nd & nd & 0.23 & 5.4 & 3.13 & 8.67 \\
\hline & $46-98$ & $\mathrm{Bt} 2$ & 3.99 & 4.77 & 0.05 & 0.03 & 0.06 & 1.86 & 3.6 & 7 & nd & 0.25 & 5.2 & 3.02 & 8.44 \\
\hline & $98-120$ & $\mathrm{Bt} 3$ & 3.97 & 4.67 & 0.03 & 0.02 & 0.04 & 1.52 & 6.1 & nd & nd & nd & 5.6 & 3.25 & 8.8 \\
\hline & $120-150$ & $\mathrm{C}$ & 3.89 & 5.23 & 0.01 & 0.03 & 0.09 & 1.56 & 11.2 & 7 & nd & nd & 7.6 & 4.41 & 11.4 \\
\hline \multirow[t]{4}{*}{ Nirwana 1} & $0-20$ & A & 3.65 & 4.28 & 0.06 & 0.07 & 0.08 & 1.78 & 9.8 & 7 & 7 & 2.28 & 9.8 & 5.68 & 14.74 \\
\hline & $20-46$ & Bt1 & 3.98 & 4.35 & 0.05 & 0.03 & 0.05 & 1.58 & 8.9 & nd & nd & 0.42 & 6.6 & 3.83 & 9.87 \\
\hline & $46-94$ & Bt2 & 3.97 & 5.68 & 0.02 & 0.05 & 0.03 & 3.04 & 5.2 & 7 & nd & nd & 5.2 & 3.02 & 7.92 \\
\hline & $94-110$ & $\mathrm{Bt} 3$ & 3.96 & 4.79 & 0.02 & 0.01 & 0.02 & 0.98 & 3.7 & 7 & nd & 0.09 & 7.8 & 4.52 & 11.75 \\
\hline \multirow[t]{4}{*}{ Nirwana 2} & $0-13$ & A & 3.53 & 4.06 & 0.05 & 0.07 & 0.07 & 0.80 & 5.1 & 28.02 & nd & 1.12 & 11.6 & 6.73 & 16.12 \\
\hline & $13-26$ & Bt1 & 3.77 & 4.41 & 0.02 & 0.02 & 0.04 & 0.78 & 2.9 & 7 & nd & 0.26 & 4.4 & 2.55 & 8.35 \\
\hline & $26-66$ & $\mathrm{Bt} 2$ & 3.91 & 4.56 & 0.02 & 0.08 & 0.03 & 0.80 & 4.2 & nd & nd & nd & 5.2 & 3.02 & 9.07 \\
\hline & $66-100$ & $\mathrm{Bt} 3$ & 3.98 & 4.56 & 0.01 & 0.03 & 0.02 & 0.67 & 2.3 & nd & nd & nd & 3.4 & 2.12 & 3.21 \\
\hline
\end{tabular}

Note: Not determined, Exch; Exchangeable, Av. Available; SEF: Soil Evaluation Factor; SFI: Soil Fertility Index

Soil organic matter was restored after 8 years of planting (Carlos et al., 1991). Based on the results of this study (Table 4), Plot 2002 (8 years after planting) had higher content of organic matter. The results (Table 4) also showed that in early years of planting, there was a low accumulation of organic matter. However, with time, it increased. This was because there was a visible decrease of SOM in early years and then the pool of soil carbon recovers, reaching the value of typical mature forest (Nadporozhskaya et al., 2006). On other hand, depth of the soil also may alter the percentage of organic matter. The result of soil profile in Table 10 showed that the content of organic matter declined with increasing depth. According to Ishizuka et al. (1998), organic matter content in the surface horizon was high due to development of root mats.

The TOC in Table 5 shows that the highest was in Plot 2002. TOC in soils is affected by the harvesting activities. After harvesting, organic matter of the soil decreases because of no input of organic matter from the plant since it was harvested. Similar results obtained as reported by Nye and Greenland (1964); Kendawang et al. (2004) and Ilstedt et al. (2004) soil organic matter declines rapidly after soil is exposed due to clearing activities. The decrease of TOC with increasing depth also correlated with the clay content in each horizon group and the decomposition rate of soil organic matter (Ohta and Effendi, 1992).

Aluminum is not considered as a plant nutrient and not useful for the growth of plants or animals. The toxicity of exchangeable aluminum will disturbed the growth of seedlings and particularly the plant growth.
According to Brown and Johnston (1982), exchangeable aluminum is higher in soils with $\mathrm{pH}$ below 5.5. The exchangeable $\mathrm{Al}$ increased with increasing depth, but in some sites, it decreased with increasing depth (Table 10). The concentrations of Al may be due to base saturation. Study conducted by Hattori et al. (2005) showed the similar results as they also conclude that the $\mathrm{Al}$ concentrations were relatively related to exchangeable bases saturation and clay content.

In Table 4, Plot 2002 had higher content of organic matter. This might have affected the CEC of the soil. Moreover, the secondary forest (Nirwana) had a different forest structure compared to the planted forest (rehabilitated forest). However, other researchers found that negative charge derived from the clay minerals affects the cation exchange capacity of clayey soils in the tropics (Ohta et al., 1993; Sakurai et al., 1998; Abdu et al., 2008).

The soil profile in the secondary and rehabilitated forests showed their CEC values decreased with depth (Table 10). However, Plot 1991 and Plot 1993 had higher CEC in the subsurface than surface soil. This may be due to soil erosion.

Ammonium and nitrate concentrations, decreased with increasing depth (Table 10), probably because population of organic decomposers in soil also relate to $\mathrm{N}$ mineralization. According to Ohta and Effendi (1992), nitrogenous compounds in the subsoil are more resistant to microbial attacks than in the surface soils.

The high content of available P in Plot 1991 may be due to application of rice straw as an organic 
fertilizer during planting. The concentrations of $\mathrm{P}$ in soils depends on a combination of factors including plant uptake, adsorption-desorption and dissolutionprecipitation of inorganic $P$, the mineralization of organic $\mathrm{P}$ and microbial immobilization and fertilizer addition (Perrott et al., 1990; Frossard et al., 2000).

However, the concentration of phosphorus in soil was influenced by some other factors. Abdu et al. (2007) carried out a study and stated that the higher clay content related to a low levels of nutrients especially available P. However, the composition of forest floor also plays an important role in concentrations of P. Study conducted by Chen et al. (2003) in unimproved grassland and 19 years old stand conclude that the recycling of $\mathrm{P}$ was mainly driven by plant $\mathrm{P}$ demand and sustained by root litter inputs and leaf litter inputs in the forest ecosystems. Besides, seasonal changes in environmental conditions such as rainfall, soil moisture and temperature also involved in the $\mathrm{P}$ availability. Microbial biomass also plays an important in $\mathrm{P}$ availability. According to Table 10, the phosphorus availability in the soil decreased with depth. A similar result has been reported by Hirai et al. (1997) and Ishizuka et al. (1998). The concentration of organic matter may play an important factor due to surface of the soils have higher organic matter.

The exchangeable bases for $\mathrm{Mg}, \mathrm{Ca}$ and $\mathrm{K}$ are decrease with increasing depth (Table 10). The nutrients were higher in the surface soil compared to subsurface soil. The bulk of organic matter and nutrients is distributed in a shallow top layer in the humid tropics (Burnham, 1984). On other hand, Ohta and Effendi (1992) stated that subsoil may be playing an important role in nutrient storage. They also assumed that some parts of the nutrients in the subsoil are pumped up slowly to the topsoil. These explain the higher accumulation of the cations in the subsoil than in the topsoil (Table 10). However, higher contents of exchangeable bases in the surface soil are due to forest litter and dead plant accumulation. Since Plot 1991 had high content of dead leaves on a forest floor. Soto and Diazfierros (1993) stated that higher contents of Ca and $\mathrm{Mg}$ in the surface horizons were probably associated with biological accumulation from plants. Besides, exchangeable $\mathrm{K}$ from the decomposition of plants might be dissolved easily into the deep layer of soil.

An SEF values less than 5 suggest extremely poor soil fertility (Lu et al., 2002). It can be concluded that there was good soil fertility status in the rehabilitated forest compared to secondary forest since the SEF value both in Nirwana 1 and Nirwana 2 were less than 5 .

For soil profile (Table 10), the soil fertility status decreased with increasing depth. The result was similar to that reported by $\mathrm{Lu}$ et al. (2002). This means vegetation growth contributes to rapid increase in soil fertility on the soil surface. However, other factors such as climate, soil parent material and time can influence soil fertility.

\section{CONCLUSION}

It can be concluded that both rehabilitated and secondary forests have significant differences based on selected physical and chemical properties. On other hand, there were significant differences based on the age of the forest in rehabilitated forest. The rehabilitated forest was more fertile compared to Nirwana forest based on the SEF values revealed that 'Miyawaki' forest rehabilitation technique is a suitable method in rehabilitating and replenishing soil fertility status of abandoned degraded shifting cultivation land.

\section{ACKNOWLEDGEMENT}

The researchers are grateful to the assistance staff of the Department of Crop Production, University Putra Malaysia, Bintulu Sarawak Campus during field sampling and laboratory analysis. This study was financially supported by the Ministry of Higher Education of Malaysia (MOHE) under Research University Grant Scheme (RUGS-03-01-09-0704) through University Putra Malaysia, Malaysia (UPM).

\section{REFERENCES}

Alexander, E.B., 1989. Bulk density equations for southern Alaska soils. Can. J. Soil Sci., 69: 177-180. DOI: $10.4141 /$ cjss89-017

Archard, F., H.D. Eva, H.J. Stibig, P. Mayaux and J. Gallego et al., 2002. Determination of deforestation rates of the world's humid tropical forests. Science, 297: 999-1002. DOI: 10.1126/science. 1070656

Abdu, A., S. Tanaka, S. Jusop, Z. Ibrahim and D. Hattori et al., 2007. Soil characteristics under rehabilitation of degraded forestland in Perak, Peninsular Malaysia. Pedologist, 51: 76-88.

Abdu, A., S. Tanaka, S. Jusop, N.M. Majid and Z. Ibrahim et al., 2008. Assessment on soil fertility status and growth performance of planted dipterocarp species in Perak, Peninsular Malaysia. J. Applied Sci., 8: 3795-3805.

Brown, A.J. and J.A. Johnston, 1982. Exchangeable aluminum in Victorian soils. Agricultural Services Library. 
Burnham, C.P., 1984. The Forest Environment: Soils. In: Tropical Rain Forests of the Far East, Whitmore, T.C. (Ed.). Oxford University Press, Oxford, pp: 137-154.

Butler, R.A., 2006. Malaysia to phase out Borneo logging in parts of Sabah State. MONGABAY.COM. http://news.mongabay.com/2006/0316-sabah.html

Carlos, C.C., B. Volkoff and F. Andreaux, 1991. Nature and behavior of organic matter in soils under natural forest and after deforestation, burning and cultivation, near Manaus. For. Ecol. Manage., 38: 247-257. DOI: 10.1016/0378-1127(91)90146-M

Chen, C.R., L.M. Condron, M.R. Davis and R.R. Sherlock, 2003. Seasonal changes in soil phosphorus and associated microbial properties under adjacent grassland and forest in New Zealand. For. Ecol. Manage., 177: 539-557. DOI: 10.1016/S03781127(02)00450-4

FAO, 2005. Global forest resources assessment 2005: Progress towards sustainable forest management. Food and Agriculture Organization of the United Nations. http://www.fao.org/docrep/008/a0400e/a0400e00.htm

Frossard, E., L.M. Conron, A. Oberson, S. Sinaj and J.C. Fardeau, 2000. Processes governing phosphorus availability in temperate soils. J. Environ. Qual., 29: 15-23. http://cat.inist.fr/?aModele=afficheN\&cpsidt=1247171

Geist, H.J. and E.F. Lambin, 2002. Proximate causes and underlying driving forces of tropical deforestation. BioScience, 52: 143-150. http://www.jstor.org/stable/1314248

Hattori, D., J. Sabang, S. Tanaka, J.J. Kendawang and I. Ninomiya et al., 2005. Soil characteristics under three vegetation types associated with shifting cultivation in a mixed dipterocarp forest in Sarawak, Malaysia. Soil Sci. Plant Nutr., 51: 231-241. DOI: 10.1111/j.1747-0765.2005.tb00027.x

Hirai, H., H. Matsumura, H. Hirotani, K. Sakurai and K. Ogino et al., 1997. Soils and the distribution of Dryobalanops aromatic and D. lanceolata in mixed dipterocarp forest. A case study at Lambir National Park, Sarawak, Malaysia. Tropics, 7: 21-33.

Ilstedt, U., A. Malmer, A. Noldgren and P. Liau, 2004. Soil rehabilitation following tractor logging: Early results on amendments and tilling in a second rotation Acacia mangium plantation in Sabah, Malaysia. For. Ecol. Manage., 194: 215-224. DOI: 10.1016/j.foreco.2004.02.032

Ishizuka, S., K. Sakurai, J. Sabang, J.J. Kendawang and H.S. Lee, 2000. Soil characteristics of an abandoned shifting cultivation land in Sarawak, Malaysia. $\quad$ Tropics, 10: 251-263. http://www.jstage.jst.go.jp/article/tropics/10/2/251/_pdf
Ishizuka, S., S. Tanaka, K. Sakurai, H. Hirai and H. Hirotani et al., 1998. Characterization and distribution of soils at Lambir Hills National Park in Sarawak, Malaysia, with special reference to soil hardness and soil texture. Tropics, 8: 31-44.

Jomo, K.S., Y.T. Chang and K.J. Khoo, 2004. Deforesting Malaysia: The Political Economy and Social Ecology of Agriculture Expansion and Commercial Logging. 1st Edn., Zed Books Limited, New York, ISBN: 978-1842774663, pp: 304.

Juo, A.S.R. and A. Manu, 1996. Chemical dynamics in slash-and-burn agriculture. Agric. Ecosyst. Environ., 58: 49-60. DOI: 10.1016/01678809(95)00656-7

Kendawang, J.J., S. Tanaka, J. Ishihara, K. Shibata and J. Sabang et al., 2004. Effect of shifting cultivation on soil ecosystem in Sarawak, Malaysia. I. Slash and burning at Balai Ringin and Sabal experimental sites and effect on soil organic matter. Soil Sci. Plant Nutr., 50: 677-687.

Kuo, S., 1996. Phosphorus. In: Method of Soil Analysis. Part 3. Chemical Methods. Sparks, D.L. (Ed.). American Society of Agronomy and Soil Science Society of America, Madison, Wisconsin, USA., pp: 869-919.

Leng, L.Y., O.H. Ahmed, N.M.A. Majid and M.B. Jalloh, 2009. Organic matter, carbon and humic acids in rehabilitated and secondary forest soils. Am. J. Applied Sci., 6: 824-828. http://www.scipub.org/fulltext/ajas/ajas65824-828.pdf

Lu, D., E. Moran and P. Mausel, 2002. Linking Amazonian secondary succession forest growth to soil properties. Land Degrad. Dev., 13: 331-343. DOI: $10.1002 / \operatorname{ldr} .516$

Mayaux, P., P. Holmgren, F. Archard, H. Eva and H.J. Stibig et al., 2005. Tropical forest cover change in the 1990s and options for future monitoring. Phil. Trans. R. Soc. B, 360: 373-384. DOI: 10.1098/rstb.2004.1590

Moran, E.F., E.S. Brondizio, J.M. Tucker, M.C. da Silva-Forsberg and S. McCracken et al., 2000. Effects of soil fertility and land use on forest succession in Amazonia. For. Ecol. Manage., 139: 93-108. DOI: 10.1016/S0378-1127(99)00337-0

Mulvaney, R.L., 1996. Nitrogen-Inorganic Forms. In: Method of Soil Analysis. Part 3. Chemical Methods, Sparks, D.L. (Ed.). American Society of Agronomy and Soil Science Society of America, Madison, Wisconsin, USA., pp: 1123-1200.

Murugayah, R.A.P., S. Gandaseca, O.H. Ahmed and N.M.A. Majid, 2009. Effect of different ages of a rehabilitated forest on selected physico-chemical properties. Am. J. Applied Sci., 6: 1043-1046. http://www.scipub.org/fulltext/ajas/ajas6610431046.pdf 
Nadporozhskaya, M.A., G.M.J. Mohren, O.G. Chertov, A.S. Komarov and A.V. Mikhailov, 2006. Dynamics of soil organic matter in primary and secondary forest succession on sandy soils in The Netherlands: An application of the ROMUL model. Ecol. Model., 190: 399-418. DOI: 10.1016/j.ecolmodel.2005.03.025

Nye, P.H. and P.J. Greenland, 1964. Changes in the soil after clearing tropical forest. Plant Soil, 21: 101-112. DOI: $10.1007 / \mathrm{BF} 01373877$

Ohta, S. and S. Effendi, 1992. Ultisols of "Lowland dipterocarp forest" in East Kalimantan, Indonesia. II. Status of carbon, nitrogen and phosphorus. Soil Sci. Plant Nutr., 38: 207-216.

Ohta, S., S. Effendi, N. Tanaka and S. Miura, 1993. Ultisols of lowland dipterocarp forest in east Kalimantan, Indonesia. III. Clay minerals, free oxides and exchangeable cations. Soil Sci. Plant Nutr., 39: 1-12.

Perrott, K.W., S.U. Sarathchandra and J.E. Waller, 1990. Seasonal storage and release of phosphorus and potassium by organic matter and the microbial biomass in a high-producing pastoral soil. Aust. J. Soil Res., 28: 593-608. DOI: 10.1071/SR9900593

Sakurai, K., B. Puriyakorn. P. Preechapanya. V. Tanpibal and K. Muangnil et al., 1995. Improvement of biological productivity in degraded lands in Thailand III. Soil hardness measurement in the field. Tropics, 4: 151-172. http://www.jstage.jst.go.jp/article/tropics/4/2_3/15 1/_pdf
Sakurai, K., S. Tanaka, S. Ishizuka and M. Kanzaki, 1998. Differences in soil properties of dry evergreen and dry deciduous forests in the Sakaerat environment research station. Tropics, 8: 61-80.

Soil Survey Staff, 1999. Keys to Soil Taxonomy. 8th Edn., Natural Resources Conservation Service, USDA., Washington, DC., pp: 869.

Soto, B. and F. Diazfierros, 1993. Interactions between plant ash leachates and soil. Int. J. Wildland Fire, 3: 207-216. DOI: 10.1071/WF9930207

Sumner, M.E. and B.A. Stewart, 1992. Soil Crusting: Chemical and Physical Processes. 1st Edn., Lewis Publishers, Boca Raton, Fla., pp: 372.

Tan, K.H., 2005. Soil Sampling, Preparation and Analysis. 2nd Edn., Taylor and Francis, USA., ISBN: 9780849334993, pp: 623.

Whitmore, T.C., 1998. An Introduction to Tropical Rain Forests. 2nd Edn., Oxford University Press, New York, ISBN: 978-0198501473, pp: 282.

Williamson, J.R. and W.A. Neilsen, 2000. The influence of forest site on rate and extent of soil compaction and profile disturbance of skid trails during ground-based harvesting. Can. J. Res. For., 30: 1196-1205. http://cat.inist.fr/?aModele=afficheN\&cpsidt=1514321

Zaidey, A.K., A. Arifin, I. Zahari, A.H. Hazandy and M.H. Zaki et al., 2010. Characterizing soil properties of lowland and hill dipterocarp forests at Peninsular Malaysia. Int. J. Soil Sci., 5: 112-113. 